\section{Calcium Application Method Impacts Botrytis Blight Severity on Petunia Flowers}

\author{
Katherine Bennett, Mary Vargo, Guido Schnabel, and James E. Faust \\ Department of Plant and Environmental Sciences, Clemson University, E143 \\ Poole Agriculture Center, Clemson, SC 29634
}

Additional index words. Botrytis cinerea, disease management, fertigation, petunia flower meltdown

\begin{abstract}
Two application methods of calcium (Ca), fertigation and spray, were investigated regarding their effects on Botrytis blight on petunia (Petunia $\times$ hybrida) flowers. Plants were grown for 6 weeks with three nutrient solutions consisting of 0,100 , or 200 $\mathrm{mg} \cdot \mathrm{L}^{-1} \mathrm{Ca}$ and weekly calcium chloride $\left(\mathrm{CaCl}_{2}\right)$ sprays of 0,750 , or $1500 \mathrm{mg} \cdot \mathrm{L}^{-1} \mathrm{Ca}$ for a total of nine treatment combinations. Flowers were harvested, inoculated with Botrytis spores, placed in humidity chambers, and evaluated for Botrytis blight severity. Disease severity decreased by $57 \%$ and $70 \%$ when flowers were treated with Ca spray applications of 750 and $1500 \mathrm{mg} \cdot \mathrm{L}^{-1} \mathrm{Ca}$, respectively; however, no change in disease severity occurred across the $\mathrm{Ca}$ fertigation applications. Ca concentration in the flower petal tissue increased with the $\mathrm{Ca}$ spray applications: the flower petal $\mathrm{Ca}$ concentration increased from $0.26 \%$ to $0.65 \%$ of tissue dry mass (DM) as the Ca spray application rate increased from 0 to $1500 \mathrm{mg} \cdot \mathrm{L}^{-1}$. However, no change was observed across the Ca fertigation treatments. Leaf tissue Ca concentration increased from $2.1 \%$ to $3.2 \% \mathrm{DM}$ as the fertigation solution increased from 0 to $200 \mathrm{mg} \cdot \mathrm{L}^{-1} \mathrm{Ca}$, whereas spray application had no significant effects of leaf tissue Ca concentration. The results demonstrate that spray application is a more effective technique than fertigation application to provide higher Ca tissue concentrations in flowers, and that the Ca concentration in flower petal tissue is an important consideration when evaluating tissue susceptibility to Botrytis blight. Because of the high rate of fungicide resistance to Botrytis cinerea found in commercial greenhouses, spray applications of $\mathrm{CaCl}_{2}$ are an important disease management tool for commercial growers.
\end{abstract}

Botrytis cinerea is a ubiquitous plant pathogen that infects bedding plants during greenhouse production, resulting in latent infections that appear in the postharvest shipping environment. On arrival at the retail location, petunias frequently exhibit symptoms of Botrytis blight on flowers consisting of tan, necrotic spots that may coalesce and lead to tissue collapse. This phenomenon is termed petunia flower meltdown, and preventive fungicide applications are the primary management technique implemented

Received for publication 25 July 2019. Accepted for publication 27 Nov. 2019.

Published online 14 January 2020.

We thank the American Floral Endowment, the Floriculture Research Alliance, and the USDAFNRI for funding this project. Special thanks to Jennifer Boldt and Douglas Sturtz of the USDAToledo for nutrient analysis of tissue samples. We also thank William Bridges for all his guidance with statistical analysis and Patricia Karen Bryson and Kelly Lewis for their technical support. Technical Contributions No. 6810 of the Clemson University Experiment Station. This material is based on work supported by the NIFA/USDA under project number SC-1700539.

J.E.F. is the corresponding author. E-mail: jfaust@ clemson.edu.

This is an open access article distributed under the CC BY-NC-ND license (https://creativecommons. org/licenses/by-nc-nd/4.0/). because of $\mathrm{Ca}$ binding with phosphate, although adequate $\mathrm{Ca}$ levels for growth do exist in the phloem (Clarkson, 1984).

Several studies have demonstrated the effect of increasing $\mathrm{Ca}$ in nutrient solutions on $\mathrm{Ca}$ concentration in leaf and flower tissue of floriculture crops. For Oriental hybrid lilies (Lilium $\times$ hybrida), increasing $\mathrm{Ca}$ concentration provided in the nutrient solution from 0 to $140 \mathrm{mg} \cdot \mathrm{L}^{-1} \mathrm{Ca}$ increased $\mathrm{Ca}$ concentration in leaves from $0.20 \%$ to $1.83 \%$ dry mass (DM); however, flower Ca concentrations were not measured (Salazar-Orozco et al., 2011). Calcium concentration in poinsettia (Euphorbia pulcherrima) leaves increased from $0.35 \%$ to $0.75 \%$ as $\mathrm{Ca}$ concentration delivered in the nutrient solution increased from 18 to $300 \mathrm{mg} \cdot \mathrm{L}^{-1} \mathrm{Ca}$ (Jacques et al., 1990). However, poinsettia bracts have low stomatal density and exhibit differences in $\mathrm{Ca}$ concentration along the margins of bracts compared with near the mid vein (Nell and Barrett, 1986), and increasing $\mathrm{Ca}$ in the nutrient solution was not effective for increasing $\mathrm{Ca}$ concentration in bract margin (Strømme et al., 1994). Roses (Rosa $\times$ hybrida) supplied with nutrient solutions containing 160 to $280 \mathrm{mg} \cdot \mathrm{L}^{-1} \mathrm{Ca}$ did not affect the $\mathrm{Ca}$ concentration of the flower petals (Baas et al., 2000). Volpin and Elad (1991) demonstrated in roses that variations can occur in $\mathrm{Ca}$ accumulation in different tissues over time; for example, increasing $\mathrm{Ca}$ in the nutrient solution from 100 to 200 $\mathrm{mg} \cdot \mathrm{L}^{-1}$ increased the Ca concentration in leaf tissue, but not in flowers, after 4 weeks. However, after 6 weeks, increasing the $\mathrm{Ca}$ concentration from 100 to $200 \mathrm{mg} \cdot \mathrm{L}^{-1}$ increased $\mathrm{Ca}$ concentration in flowers but not in leaves. Starkey and Pedersen (1997) demonstrated that increasing the $\mathrm{Ca}$ supplied in nutrient solutions by 44 to $176 \mathrm{mg} \cdot \mathrm{L}^{-1}$ increased $\mathrm{Ca}$ concentration of the flowers and buds of potted roses from $0.4 \%$ to $0.6 \% \mathrm{Ca}$ and increased $\mathrm{Ca}$ concentration in leaves from $0.7 \%$ to $1.6 \%$. Although increasing $\mathrm{Ca}$ concentration in flower tissue is possible through the nutrient solution, previous research demonstrated that this method does not yield consistently positive results.

Calcium spray applications provide an additional strategy for increasing Ca concentration in low transpiring tissues such as flowers or fruits. Calcium spray applications of $432 \mathrm{mg} \cdot \mathrm{L}^{-1} \mathrm{Ca}$ alleviated bract-edge burn in poinsettia, which is caused by a localized Ca deficiency occurring on the margins of the bracts (Harbaugh and Woltz, 1989). As the $\mathrm{Ca}$ concentration of the bract margin increased from $0.12 \%$ to $0.17 \% \mathrm{DM}$, bractedge burn decreased. Tomato plants supplied with a low rate of $\mathrm{Ca}\left(11.6 \mathrm{mg} \cdot \mathrm{L}^{-1}\right)$ in the nutrient solution and a high rate in the spray solution $\left(1200 \mathrm{mg} \cdot \mathrm{L}^{-1} \mathrm{Ca}\right)$ had increased $\mathrm{Ca}$ concentrations in the fruit and decreased incidence of blossom end rot (SchmitzEiberger et al., 2002).

Calcium can be delivered to plants by the fertigation solution delivered to the roots or by spray application to the aboveground tissues. The objective of this study was to 
Table 1. Calculated values of nutrients for the three calcium (Ca) treatments supplied in the fertigation solutions and the measured values of $\mathrm{pH}$ and electrical conductivity (EC). Sodium chloride was added to the 0 and $100 \mathrm{mg} \mathrm{L}^{-1} \mathrm{Ca}$ solutions to provide the same EC for each solution.

\begin{tabular}{|c|c|c|c|c|c|c|c|c|c|c|c|c|c|c|}
\hline $\mathrm{Ca}$ & $\mathrm{N}$ & $\mathrm{P}$ & $\mathrm{K}$ & $\mathrm{Mg}$ & $\mathrm{S}$ & $\mathrm{Fe}$ & $\mathrm{Mn}$ & $\mathrm{B}$ & $\mathrm{Cu}$ & $\mathrm{Zn}$ & $\mathrm{Cl}$ & $\mathrm{Na}$ & \multirow[b]{2}{*}{$\mathrm{EC}\left(\mathrm{dS} \cdot \mathrm{m}^{-1}\right)$} & \multirow[b]{2}{*}{$\mathrm{pH}$} \\
\hline \multicolumn{13}{|c|}{$\left(\mathrm{mg} \cdot \mathrm{L}^{-1}\right)$} & & \\
\hline 100 & 100 & 20 & 150 & 50 & 40 & 1.05 & 0.53 & 0.26 & 0.53 & 0.53 & 385 & 133 & 2.5 & 6.0 \\
\hline
\end{tabular}

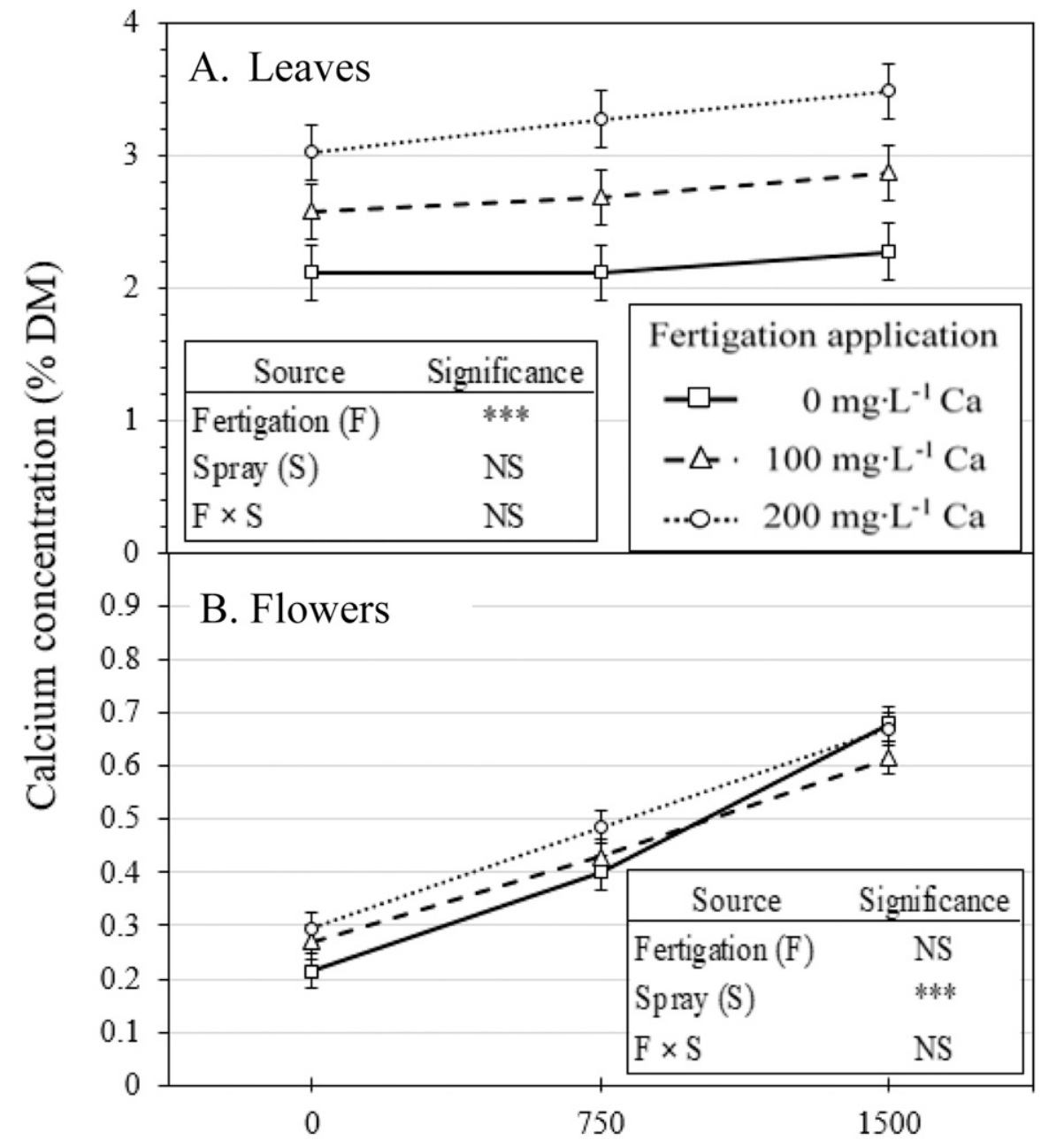

Calcium spray application rate $\left(\mathrm{mg} \cdot \mathrm{L}^{-1}\right)$

Fig. 1. Calcium (Ca) concentration (\% dry mass, DM) in petunia leaves $(\mathbf{A})$ and flowers $(\mathbf{B})$ on plants grown with three $\mathrm{Ca}$ concentrations provided during daily fertigation applications and three $\mathrm{Ca}$ concentrations provided during weekly spray applications for 3 weeks. Analysis of variance results of the main effects are presented in each figure. Interactions were nonsignificant. Errors bars represent $\pm 1 \mathrm{SE}$.

determine the effects of $\mathrm{Ca}$ application methods and $\mathrm{Ca}$ concentrations in the application solutions on the $\mathrm{Ca}$ concentration in petunia leaf and flower petals and on the susceptibility of the flowers to Botrytis blight.

\section{Materials and Methods}

Two methods (fertigation and spray) of $\mathrm{Ca}$ application were compared; three concentrations of Ca were used for each method. More specifically, three fertigation solutions $(0,100$, and $200 \mathrm{mg} \cdot \mathrm{L}^{-1} \mathrm{Ca}$ ) and three spray solutions $\left(0,750\right.$, and $\left.1500 \mathrm{mg} \cdot \mathrm{L}^{-1} \mathrm{Ca}\right)$ were applied, for a total of nine treatment combinations, using a
(Fafard 3B; Conrad Fafard, Inc., Agawam, MA) containing an initial $\mathrm{Ca}$ concentration of $1.5 \% \mathrm{Ca}$. Plants were grown in a glass greenhouse (lat. $35^{\circ} \mathrm{N}$ ) with heating and cooling setpoints of 21 and $24{ }^{\circ} \mathrm{C}$, respectively. Long days were provided with daylength extension lighting with metal halide lamps when solar radiation was $<200 \mathrm{~W} \cdot \mathrm{m}^{-2}$ from 0900 to 2400 HR to promote flowering of this facultative long day species from February to May. During the 6 weeks when $\mathrm{Ca}$ treatments were provided, the vapor pressure deficit averaged $1.24 \pm 0.07$ $\mathrm{kPa}$. The plants were fertilized during each irrigation event for 3 weeks after transplantation with Jack's Professional 15-5-15 Calcium + Magnesium LX (15 N, 2.2 P, 12.5 K, 4 Ca, 2 $\mathrm{Mg}$; JR Peters Inc., Allentown, PA), providing $100 \mathrm{mg} \cdot \mathrm{L}^{-1} \mathrm{~N}$ and $26 \mathrm{mg} \cdot \mathrm{L}^{-1} \mathrm{Ca}$.

Three weeks after transplantation, the fertigation and spray application treatments were initiated. The experiment used 12 plants per treatment, for a total of 108 plants. The fertigation treatments consisted of a constant liquid fertilization program providing $200 \mathrm{~mL}$ of fertigation solution per container each day between 0800 and 0830 HR for 6 weeks. To avoid confounding the $\mathrm{Ca}$ fertigation treatments with the electrical conductivity (EC) of the fertigation solution, the fertigation solutions were adjusted with sodium chloride $(\mathrm{NaCl})$ so that all solutions had an EC of $2.5 \mathrm{dS} \cdot \mathrm{m}^{-1}$, which was the initial EC of the $200 \mathrm{mg} \cdot \mathrm{L}^{-1} \mathrm{Ca}$ solution (Table 1). Calcium spray applications occurred weekly during the same 6 weeks when fertigation treatments were applied. For the spray application treatments, $\mathrm{CaCl}_{2}$ (anhydrous 96\% purity; Thermo Fisher Scientific, Waltham, MA) was dissolved in deionized water to provide solutions containing 0,750 , or $1500 \mathrm{mg} \cdot \mathrm{L}^{-1}$ $\mathrm{Ca}$. The spray application rate was $204 \mathrm{mg} \cdot \mathrm{L}^{-1}$, and the applications were performed between 1600 and 1700 HR using hand sprayers.

After providing the nine combinations of fertigation and spray treatments for 3 weeks, two plants per treatment were randomly selected and destructively harvested for nutrient analysis of the fully expanded green leaves and open flowers. All flowers were harvested without their peduncle and sepals. The collected tissues were dried in an oven at $60{ }^{\circ} \mathrm{C}$, ground to a fine powder, and submitted for nutritional analysis (ICP-OES; Thermo Scientific) performed at the Agricultural Research Service of the United States Department of Agriculture (USDA-ARS, Toledo, $\mathrm{OH}$ ).

During the final 3 weeks of the experiment, three to four freshly opened flowers per plant were harvested $24 \mathrm{~h}$ after the weekly spray application and inoculated with Botrytis spores $\left(10^{4}\right.$ spores $\left./ \mathrm{mL}\right)$. All open flowers were removed the day before each spray application 


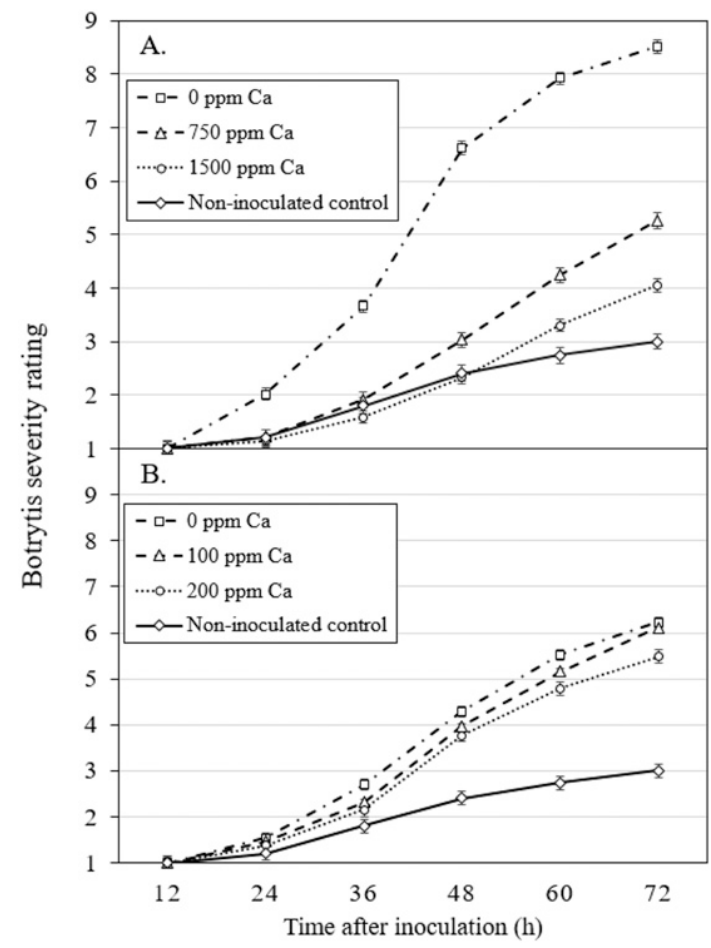

Fig. 2. The Botrytis severity rating (scale: $1=0 \%, 2=0 \%$ to $2 \%, 3=2 \%$ to $5 \%, 4=5 \%$ to $10 \%, 5=10 \%$ to $25 \%, 6=25 \%$ to $50 \%, 7=50 \%$ to $75 \%, 8=75 \%$ to $100 \%, 9=100 \%$ of the flower petal was infected) was recorded for individual flowers every $12 \mathrm{~h}$ for $72 \mathrm{~h}$ following inoculation with a conidial suspension. Main effect means are displayed for (A) the three spray applications $\left(0,750\right.$, or $\left.1500 \mathrm{mg} \cdot \mathrm{L}^{-1} \mathrm{Ca}\right)$ and $(\mathbf{B})$ the three fertigation applications $\left(0,100\right.$, or $\left.200 \mathrm{mg} \cdot \mathrm{L}^{-1} \mathrm{Ca}\right)$. The noninoculated control is shown in both figures. Errors bars represent \pm 1 SE.

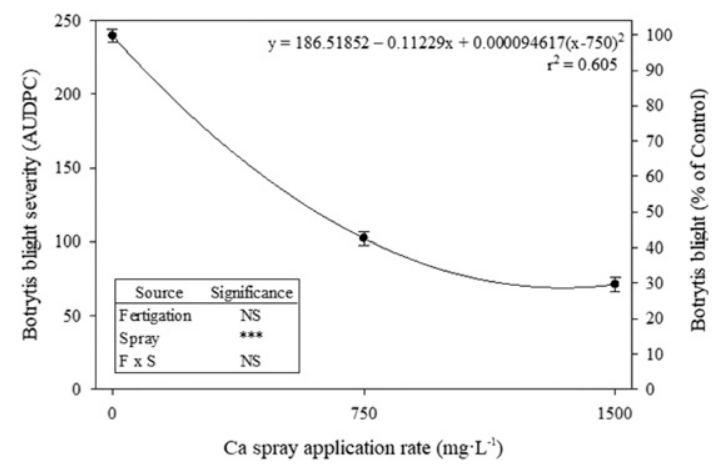

Fig. 3. Botrytis blight severity on petunia flowers following weekly calcium (Ca) spray applications using calcium chloride $\left(\mathrm{CaCl}_{2}\right)$. Botrytis blight severity is expressed as the sum of the area under the disease progression curve (AUDPC) (left) and as a percentage of the control treatment (right). Analysis of variance results for the main effects are presented. Error bars represent $\pm 1 \mathrm{SE}$.

so that only freshly opened flowers were used for Botrytis blight evaluation. Inoculated flowers were then evaluated every $12 \mathrm{~h}$ for $72 \mathrm{~h}$ using a rating scale $(1=0 \%, 2=0 \%$ to $2 \%$, $3=2 \%$ to $5 \%, 4=5 \%$ to $10 \%, 5=10 \%$ to $25 \%$, $6=25 \%$ to $50 \%, 7=50 \%$ to $75 \%, 8=75 \%$ to $100 \%, 9=100 \%$ of the flower petal was infected). Botrytis inoculations were conducted during each week of the final 3 weeks of the experiment, for a total of three replications.

Data analysis. Data analysis was performed using JMP Pro version 13.2.0 (SAS Institute Inc., Cary, NC). An analysis of variance (ANOVA) was used to determine treatment effects for the calcium tissue analysis of flowers and leaves. The data set consisted of two separate ANOVA tables for leaves and flowers, with both consisting of a $3 \times 3$ factorial model for the three fertigation treatments and three spray treatments.

For Botrytis blight severity data, an ANOVA was used to determine treatment effects. Treatments were analyzed using the area under the disease progression curve (AUDPC), as previously described by Bennett (2019). Regression analysis was also performed for Botrytis blight severity data using JMP Quadratic Fit.

\section{Results and Discussion}

The main effect of fertigation application was the only significant factor to affect $\mathrm{Ca}$ concentration within petunia leaf tissue
(Fig. 1A). Leaf tissue $\mathrm{Ca}$ concentration increased from $2.1 \%$ to $3.2 \% \mathrm{DM}$ as the fertigation solution increased from 0 to 200 $\mathrm{mg} \cdot \mathrm{L}^{-1} \mathrm{Ca}$. For petunia flowers, the main effect of the spray application was the only significant factor affecting the $\mathrm{Ca}$ concentration in the tissue (Fig. 1B). The Ca concentration in flower petal tissue increased from $0.26 \%$ to $0.65 \% \mathrm{DM}$ as the spray solution increased from 0 to $1500 \mathrm{mg} \cdot \mathrm{L}^{-1} \mathrm{Ca}$. No interactions between the fertigation and spray application treatments on the leaf and flower petal were observed (Fig. 1).

The Botrytis severity rating for the inoculated control increased from 1 to 8.6 over the course of $72 \mathrm{~h}$ after inoculation, whereas the final ratings for 750 and $1500 \mathrm{mg} \cdot \mathrm{L}^{-1} \mathrm{Ca}$ spray application treatments were 5.3 and 3.9 , respectively (Fig. 2A). The noninoculated control was rated 3.0 after $72 \mathrm{~h}$ in the humid chambers. This value provided a baseline value for the naturally occurring disease pressure. The Botrytis severity rating for the three fertigation treatments ranged from 5.5 to 6.2 at the end of the evaluation period (Fig. 2B).

The AUDPC indicated that Botrytis blight severity decreased by $70.3 \%$ as the $\mathrm{Ca}$ concentration in the spray application treatment increased from 0 to $1500 \mathrm{mg} \cdot \mathrm{L}^{-1} \mathrm{Ca}$ (Fig. 3). The $\mathrm{Ca}$ concentration delivered in the fertigation solution did not affect Botrytis blight severity. No significant interaction between the fertigation and spray application treatments on Botrytis blight severity occurred.

During commercial production of petunias, application of $\mathrm{Ca}$ to plants primarily occurs through the nutrient solution. A typical nutrition program for petunia production using constant liquid fertilization provides 100 $\mathrm{mg} \cdot \mathrm{L}^{-1} \mathrm{~N}$. The $\mathrm{Ca}$ concentration in these solutions typically ranges from 17 to 33 $\mathrm{mg} \cdot \mathrm{L}^{-1}$, depending on the formulation of preblended fertilizer used. Additional $\mathrm{Ca}$ in the nutrient solution may result from naturally occurring $\mathrm{Ca}$ in the water source (e.g., $\mathrm{Ca}$ levels can vary from 0 to $100 \mathrm{mg} \cdot \mathrm{L}^{-1}$, depending on the water source) (Morr et al., 2006)

The standard range for $\mathrm{Ca}$ concentration in leaf tissue of petunia has been reported to be $1.2 \%$ to $2.8 \%$ DM (Jones and Mills, 1996); however, in our study, petunia leaves ranged from $2.2 \%$ to $3.3 \%$ DM with the 0 to $200 \mathrm{mg} \cdot \mathrm{L}^{-1}$ $\mathrm{Ca}$ fertigation application treatments. Calcium concentration in petunia leaves increased $19.9 \%$ when the $\mathrm{Ca}$ provided in the nutrient solution increased from 0 to $100 \mathrm{mg} \cdot \mathrm{L}^{-1}$; when $\mathrm{Ca}$ concentration in the nutrient solution increased from 100 to $200 \mathrm{mg} \cdot \mathrm{L}^{-1} \mathrm{Ca}$, the $\mathrm{Ca}$ concentration in the leaves increased by an additional $16.8 \%$. Petunia plants supplied only with $\mathrm{Ca}$ in the nutrient solution, regardless of Ca concentration, had flower petal tissue of $0.26 \% \mathrm{Ca}$, which was 12-times lower than the $\mathrm{Ca}$ concentration of leaves from plants that were provided with 200 $\mathrm{mg} \cdot \mathrm{L}^{-1} \mathrm{Ca}$ in the nutrient solution. These results demonstrate that constant liquid fertilization is an ineffective method of increasing $\mathrm{Ca}$ concentration in petunia flower petals.

Calcium spray applications effectively increased flower petal $\mathrm{Ca}$ concentration and reduced Botrytis blight severity in petunia 
flowers. Direct applications of Ca from sprays allowed flower tissue to acquire $\mathrm{Ca}$, whereas supplying $\mathrm{Ca}$ through fertigation did not increase $\mathrm{Ca}$ in flower tissue or decrease Botrytis blight severity. These results demonstrate that supplying $\mathrm{Ca}$ in the fertigation solution is not sufficient for increasing $\mathrm{Ca}$ in flower tissue or decreasing Botrytis blight severity of those flowers. As a result, Ca spray applications are necessary to reduce the susceptibility of petunia flowers to Botrytis blight.

Two modes of action are suggested for the effects of $\mathrm{Ca}$ on Botrytis. The first involves $\mathrm{Ca}$ binding with pectin (polygalacturonic acid chains) in the middle lamella forming Ca-pectate, which is important for strengthening cell walls. Crosslinks between $\mathrm{Ca}$ and pectin favor the formation of a gel that makes pectin spatially less accessible to polygalacturonases (Conway and Sams, 1984), which are enzymes produced by Botrytis to degrade host cell walls (Cabanne and Donèche, 2002). The second mode of action suggests a direct effect of $\mathrm{Ca}$ on polygalacturonase production and on Botrytis hyphal growth. Volpin and Elad (1991) showed that polygalacturonase activity and hyphal growth were inhibited by increasing Ca concentration in vitro from 0 to $120 \mathrm{mg} \cdot \mathrm{L}^{-1} \mathrm{Ca}$. Similar results have been found in Botrytis isolates from grapes when grown in vitro with $\mathrm{Ca}$ ranging from 145 to $582 \mathrm{mg} \cdot \mathrm{L}^{-1}$ (Nigro et al., 2006). Cabanne and Donèche (2002) reported $90 \%$ inhibition of polygalacturonase activity in an in vitro solution containing $40 \mathrm{mg} \cdot \mathrm{L}^{-1} \mathrm{Ca}$, which is a concentration similar to naturally occurring $\mathrm{Ca}$ concentration in grapes; they concluded that increasing $\mathrm{Ca}$ concentration in fruits may allow for increased resistance from the tissue by acting as an enzyme inhibitor.

Several studies have examined the effects of $\mathrm{Ca}$ on Botrytis infection. Bract-edge burn of poinsettia has the initial symptoms of necrotic spotting along bract margins due to a localized $\mathrm{Ca}$ deficiency that later succumbs to Botrytis infection and causes the necrotic spots to expand and coalesce. Harbaugh and Woltz (1989) demonstrated that weekly Ca spray applications of $432 \mathrm{mg} \cdot \mathrm{L}^{-1} \mathrm{Ca}$ reduced the number of bract-edge burn lesions by $94 \%$. Starkey and Pedersen (1997) reported a decrease in Botrytis blight of potted rose flowers and buds with increasing Ca concentrations in the nutrient solution. De Capdeville et al. (2005) also demonstrated that Ca spray applications of 400 and $800 \mathrm{mg} \cdot \mathrm{L}^{-1}$ Ca effectively reduced Botrytis blight severity of cut rose flowers by $68 \%$ and $76 \%$, respectively. Álvarez et al. (2012) demonstrated a significant reduction in Botrytis blight severity from naturally occurring Botrytis populations following $\mathrm{CaCl}_{2}$ spray applications of $1000 \mathrm{mg} \cdot \mathrm{L}^{-1} \mathrm{Ca}$.

Results from a previous study determined that neither the chloride anion nor the EC of the spray solution contribute to the reduction in Botrytis blight following spray applications of $\mathrm{CaCl}_{2}$ (Bennett, 2019). Therefore, the reduction of Botrytis blight severity on petunia flowers following $\mathrm{CaCl}_{2}$ applications is solely due to $\mathrm{Ca}$ in the solution.

In conclusion, the results of this study demonstrate the effectiveness of $\mathrm{Ca}$ spray applications to increase $\mathrm{Ca}$ content of petunia flowers and decrease Botrytis blight severity. In contrast, increasing $\mathrm{Ca}$ in the fertigation solution effectively increased $\mathrm{Ca}$ concentration in the leaves, but increasing $\mathrm{Ca}$ in the spray applications did not. Therefore, $\mathrm{Ca}$ spray applications are not necessary to increase Ca concentration of leaves, and fertigation applications with increased $\mathrm{Ca}$ concentration could be used to potentially increase $\mathrm{Ca}$ in leaves of species that are susceptible to Botrytis. Tissue analysis results suggest that $\mathrm{Ca}$ concentration of petunia flower petals should not be less than $0.4 \%$ DM to decrease petal susceptibility to Botrytis infection. This study demonstrates the potential usefulness of Ca spray applications during greenhouse production as an alternative method of fungicide application for $\mathrm{Bo}$ trytis management.

\section{Literature Cited}

Álvarez, H.A. 2012. Efecto del manejo nutricional del calcio en la expresion de Botrytis cinerea en flores y tallos de Rosa sp. MS Thesis, Repositorio institucional UN, Universidad Nacional de Colombia.

Baas, R., N. Marissen, and A. Dik. 2000. Cut rose quality as affected by calcium supply and translocation. Acta Hort. 518:45-54.

Bennett, K. 2019. The effect of calcium on Botrytis blight of petunia flowers. MS Thesis, Clemson Univ, Clemson.

Cabanne, C. and B. Donèche. 2002. Purification and characterization of two isozymes of polygalacturonase from Botrytis cinerea. Effect of calcium ions on polygalacturonase activity. Microbiol. Res. 157:183-189.

Clarkson, D.T. 1984. Calcium transport between tissues and its distribution in the plant. Plant Cell Environ. 7:449-456.

Conway, W.S. and C.E. Sams. 1984. Possible mechanisms by which postharvest calcium treatment reduces decay in apples. Phytopathology 74:208-210.

De Capdeville, G., L.A. Maffia, F.L. Finger, and U.G. Batista. 2005. Pre-harvest calcium sulfate applications affect vase life and severity of gray mold in cut roses. Scientia Hort. 103:329-338.

Harbaugh, B.K. and S.S. Woltz. 1989. Fertilization practice and foliar-bract calcium sprays reduce incidence of marginal bract necrosis of poinsettia. HortScience 24:465-468.

Jacques, D.J., R.E.J. Boerner, and J.C. Peterson. 1990. Effects of Ca supply and stress on uptake and translocation of $\mathrm{Ca}$ in two poinsettia cultivars. Environ. Expt. Bot. 30:525-531.

Jones, J.B., Jr. and H.A. Mills. 1996. Plant analysis handbook. A practical sampling, preparation, analysis, and interpretation guide. 2nd ed. Micro-Macro Publishing, Inc., Athens, GA.

Morr, S., E. Cuartas, B. Alwattar, and J.M. Lane. 2006. How much calcium is in your drinking water? A survey of calcium concentrations in bottled and tap water and their significance for medical treatment and drug administration. HSS J. 2:130-135.

Nell, T.A. and J.E. Barrett. 1986. Growth and incidence of bract necrosis in 'Gutbier V-14 Glory' poinsettia. J. Amer. Soc. Hort. Sci. 111:266-269.

Nigro, F., L. Schena, A. Ligorio, I. Pentimone, A. Ippolito, and M.G. Salerno. 2006. Control of table grape storage rots by pre-harvest applications of salts. Postharvest Biol. Technol. 42: 142-149.

Roddy, A.B., C.R. Brodersen, and T.E. Dawson. 2016. Hydraulic conductance and the maintenance of water balance in flowers. Plant Cell Environ. 39:2123-2132.

Salazar-Orozco, G., L.A. Valdez-Aguilar, J. TelloMarquina, A. Grassotti, G. Burchi, and A.M. Castillo-González. 2011. Calcium affects quality and nutrition of cut lily flowers. Acta Hort. 900:113-117.

Samarakoon, U.C., G. Schnabel, J.E. Faust, K. Bennett, J. Jent, M.J. Hu, S. Basnagala, and M. Williamson. 2017a. First report of resistance to multiple chemical classes of fungicides in Botrytis cinerea, the causal agent of gray mold from greenhouse-grown petunia in Florida. Plant Dis. 101:1052.

Samarakoon, U.C., J.E. Faust, and J.M. Dole. 2017b. Quantifying the effects of foliarapplied calcium chloride and its contribution to postharvest durability of unrooted cuttings. HortScience 52:1790-1795.

Schmitz-Eiberger, M., R. Haefs, and G. Noga. 2002. Calcium deficiency-influence on the antioxidative defense system in tomato plants. J. Plant Physiol. 159:733-742.

Starkey, K.R. and A.R. Pedersen. 1997. Increased levels of calcium in the nutrient solution improves the postharvest life of potted roses. J. Amer. Soc. Hort. Sci. 122:863-868.

Strømme, E., A.R. Selmer-Olsen, H.R. Gislerod, and R. Moe. 1994. Cultivar differences in nutrient absorption and susceptibility to bract necrosis in poinsettia (Euphorbia pulcherrima Willd. ex Klotzsch). Gartenbauwissenschaft 59:6-12.

Volpin, H. and Y. Elad. 1991. Influence of calcium nutrition on susceptibility of rose flowers to Botrytis blight. Phytopathology 81:1390-1394. 